\title{
EUROPEAN EXPERIENCE OF SUPPORTING YOUTH BUSINESS INITIATIVES IN SOCIAL ECONOMY
}

\author{
Pereverzieva A.V., Osaul A.O. \\ Zaporizhzhia National University \\ Ukraine, 69600, Zaporizhzhia, Zhukovsky str., 66 \\ pereverzeva@ukr.net, alinaosaul@ukr.net, \\ ORCID. 0000-0001-8391-6636, ORCID 0000-0002-5194-9799
}

Key words:

social entrepreneurship, social business, youth initiatives,

European experience,

development, social economy, employment, stability.
The article is devoted to the study of youth business initiatives in the social economy by supporting the development of social entrepreneurship. Based on a comparative analysis with traditional forms of management and the authors identified features of social entrepreneurship, including: monitoring and ranking of social problems that need to be addressed; focus on solving a certain social problem based on the use of the most effective business practices; the presence of an innovative component, ie the production of goods or services that have not previously existed in the market and that create added value; distribution of income for investing the received net income in the implementation of the social task defined at the initial stage of establishment of the enterprise. Based on the study of European experience, the areas of social enterprises that are the basis for youth employment are identified, namely: integration into the work environment, which involves the adaptation of people with disabilities to working conditions, providing their education, training; private social services - health care, livelihoods, medical services, education services, assistance to vulnerable groups, the elderly, people who have lost their ability to work; discrete development, ie the development of local environments, especially backward areas - stagnation and development of social enterprises in remote areas, especially in rural areas, the restoration of social infrastructure in remote industrial areas; other areas and spheres - processing, protection and maintenance of environmental balance, cultural development and preservation of cultural heritage, art, science, innovative development, respect for consumer rights. It is substantiated that the modern world trend is to form and support the functioning of an inclusive team by attracting people who may differ in experience, gender, age, nationality, lifestyle, cultural characteristics, temperament, attitude to work, results and more.

\section{ЄВРОПЕЙСЬКИЙ ДОСВІД ПІТРИМКИ БІЗНЕС-ІНІЦІАТИВИ МОЛОДІ В УМОВАХ СОЦАЛЬНОЇ ЕКОНОМІКИ}

\author{
Переверзсва А.В., Осаул А.О. \\ Запорізький національний університет \\ Україна, 69000, м. Запоріжжя, вул. Жуковського, 66
}

\section{Ключові слова:}

соціальне підприємництво, соціальний бізнес, молодіжні ініціативи, європейський досвід, розвиток, соціальна економіка, зайнятість, стабільність.
Стаття присвячена дослідженню молодіжних бізнес-ініціатив в умовах соціальної економіки шляхом підтримки розвитку соціального підприємництва. На основі порівняльного аналізу з традиційними формами господарювання i авторами виокремлено ознаки соціального підприємництва, серед яких: моніторинг і ранжування соціальних проблем, що потребують першочергового вирішення; орієнтація на вирішення визначеної соціальної проблеми на основі використання найефективніших практик підприємницької діяльності; наявність інноваційної складової, тобто продукування товарів або надання послуг, яких переважно до цього часу не існувало на ринку та котрі створюють додаткову цінність; розподіл доходів щодо інвестування отриманого чистого доходу в реалізацію соціального завдання, визначеного на початковому етапі створення підприємства. На основі вивчення європейського досвіду визначено напрями діяльності соціальних підприємств, які $\epsilon$ базою для забезпечення зайнятості молоді, а саме: інтеграція в середовище праці, що передбачає адаптацію людей з обмеженими можливостями до умов 
праці, забезпечення їх навчання, підвищення кваліфікації; приватні послуги соціального спрямування - охорона здоров'я, забезпечення життєдіяльності, надання медичних послуг, послуг освіти, допомога незахищеним верствам населення, людям похилого віку, людям, котрі втратили працездатність; дискретний розвиток, тобто розвиток локальних середовищ, особливо відсталих територій - застування та розвиток соціальних підприємств на віддалених територіях, особливо сільській місцевості, відновлення соціальної інфраструктури у віддалених промислових районах; інші напрями та сфери переробка, охорона та підтримка збалансованості навколишнього середовища, культурний розвиток та збереження культурної спадщини, мистецтво, наука, інноваційний розвиток, дотримання прав споживачів. Обгрунтовано, що сучасним світовим трендом є формування та підтримка функціонування інклюзивного колективу шляхом залучення до праці людей, які можуть різнитися досвідом, статтю, віком, національністю, стилем життя, культурними особливостями, темпераментом, ставленням до праці, результату та інше.

\section{Statement of the problem}

Nowadays there is a growing need for the introduction and improvement of social entrepreneurship caused by the uneven income distribution in society, low purchasing power of population and lack of full current social needs satisfaction. Social entrepreneurship as innovative form of business allows to solve social problems, i.e. new jobs creation, improvement of nation level and quality of life and life-long development of each individual. As it is impossible to ensure proper social development at the national level, there is a need to find effective methods of maintaining social balance at the local and sub-regional levels of a society.

\section{Analysis of recent studies and publications}

Issues of support and development of youth entrepreneurship in the context of European integration are reflected in the scientific works of Ukrainian and foreign researchers. Directions and methods of stimulating youth business initiatives are presented in the works of foreign scholars, such as S. Papadaki, P. Novak, J. Dvorsky and others. Among Ukrainian scientists, the issues of youth employment and self-realization were analyzed by Yu. Belkin, M. Holovaty, O. Pustovoit and others. There is a need of more in-depth study of the formation of social enterprises as a way to realize the potential of young people amid the dominance of social-biased business.

\section{Objectives of the article}

The objective of the study is to identify and analyze business initiatives for young people in the social economy to determine effective forms of employment and their selfrealization.

\section{The main material of the research}

Experience of countries with low social expenditure prove their low standard of living. Amid permanent crisis, the issue of ensuring the well-being of population arises and centralization of available resources becomes relevant. Social entrepreneurship is becoming the main source of stability in society [1]. The task of the need to create and operate social enterprises is exacerbated by the state inability to ensure appropriate level of socio-economic development, lower disparities in income distribution and social inequality, etc. Therefore, there is a need to use market methods and innovative business models that will complement government regulation methods. However, the optimal ratio between state and market levers in regulating the activities of enterprises depends on the national economies' characteristics. The governmental role involves creating favourable business environment and development of this form of management, but typically it is a private initiative. A social enterprise, as well as traditional forms of business, is characterized by the necessity to determine the performance effectiveness, its long term planning and forecasting. The latter requires evaluation methods for activities efficiency. An ideal model of social entrepreneurship is debatable as it has national specifics, allows to solve urgent social problems and provides a material reward for a social entrepreneur. As a rule, it is quite difficult to balance "desirable" and "possible". Let us admit that the form of economic activity requires certain individual characteristics of a social entrepreneur, as well as appropriate professional and practical training. Moreover, the improvement of education system, practical training of social-biased managers who are ready to fulfill their social mission remain important [2]. Let us emphasize that social entrepreneurship aims at identification and practical solution of social issues using innovative methods or creative ways to adapt traditional business experience to the market environment [3]. That is, a social problem necessitates the development of social entrepreneurship in a particular industry.

Thus, we can conclude that social entrepreneurship compared to the traditional forms of economic activity has its own characteristics (Table 1). The degree of company's "sociality" is determined by four key factors, combined by the ability to take the initiative, contribute to the development of social welfare in general and ensure own professional growth, affect quality of life in particular.

It should be noted that there is no clear definition of social entrepreneurship, but there is an awareness and understanding around the world of its key target characteristics: the main goal of a social enterprise is social effect, but not profit-seeking for owners or shareholders. The model of the business functioning in the market involves the production of goods and services using the profits to achieve 
social goals. That is, the international concept [5] of social entrepreneurship combines the concepts of non-profit sector and social economy, focusing on a new entrepreneurial initiative that pursues social goals.

Table 1 - Social entrepreneurship peculiarities in comparison with traditional business forms

\begin{tabular}{|c|}
\hline $\begin{array}{c}\text { Social entrepreneurship as the following peculiarities: } \\
\text { monitoring and social problems ranking } \\
\text { to be addressed as a matter of priority }\end{array}$ \\
\hline $\begin{array}{c}\text { focusing on solving certain social problems based } \\
\text { on the most efficient business practices }\end{array}$ \\
\hline $\begin{array}{c}\text { an innovative component, i.e. production of goods or services, } \\
\text { which did not exist on the market and have added value }\end{array}$ \\
\hline $\begin{array}{c}\text { income distribution aimed at investment of the gained net } \\
\text { income into the social task defined at the initial stage } \\
\text { of business activity }\end{array}$ \\
\hline
\end{tabular}

Source: grouped by the authors on the basis of: [4]

Foreign scholars [4] traditionally allocate four basic spheres of social enterprises activity: integration of labour resources - training and employment of people with disabilities, people in difficult life circumstances and unemployed; provision of individual social services in such areas as health care, social protection, vocational training, education, social adaptation, etc.; local and sub-regional development of depressed or vulnerable areas and regions; ecosystems preservation, sports, art, crafts, culture, science, research and innovation, consumer protection and more.

It should be pointed out that foreign models of social entrepreneurship have strong government effect (Table 2).

Table 2 - Foreign models of social entrepreneurship

\begin{tabular}{|c|c|}
\hline Models & State in social enterprises support \\
\hline $\begin{array}{c}\text { Belgium, Netherlands, } \\
\text { Norway, Sweden }\end{array}$ & $\begin{array}{c}\text { Strong support for the development } \\
\text { of social entrepreneurship } \\
\text { at the legislative level }\end{array}$ \\
\hline USA, Canada, Japan & Business level regulation, charity \\
\hline $\begin{array}{c}\text { Austria, Germany, } \\
\text { France }\end{array}$ & $\begin{array}{c}\text { targeted comprehensive social } \\
\text { programmes for social enterprises and } \\
\text { implementation of joint business projects }\end{array}$ \\
\hline Great Britain & Social investment for businesses \\
\hline
\end{tabular}

Source: combined by the author on the basis of: [5]

Based on the foreign models analysis presented in Table 2, it should be noted that the model of Belgium, the Netherlands, Norway and Sweden supports appropriate legal framework, for example "social purpose companies" (Belgium), which promote social entrepreneurship. The United States, Canada and Japan are characterized by the regulation at enterprise level, as there are no requirements for managerial methodology and legal status of a social enterprise, charity is based on interest-free loans or minimum interest rate.

We would like to stress that the European model of social entrepreneurship is characterized mainly by its focus on social goals. In Europe, social entrepreneurship is largely linked to the interaction between community and commercial organizations. Thus, in the European context, a "social enterprise" is an innovative and commercial approach to solving social problems. It is followed by the organization in the process of its business development. It is implemented mainly through non-profit organizations to apply in profit-seeking activity.

European experience in social entrepreneurship differs significantly. Firstly, it is strong centralized role of the state in social support and assistance to certain groups of residents. Second, some countries have similar definitions for "social enterprise" and "social cooperatives". Social entrepreneurship is not just a method of solving social problems, but one of the drivers of the European economy.

In the EU countries, social enterprises are commonly focused on businesses providing jobs:

a) integration into the work environment, i.e. adaptation of people with disabilities to working conditions, supporting their training and advanced training;

b) private social services (health care, medical and education services, assistance to vulnerable groups of people, the elderly);

c) discrete development, i.e. the development of local territories, especially depressed ones - start and development of social enterprises in remote areas, especially in rural areas, restoration of social infrastructure in remote industrial areas;

d) other trends and spheres. i.e. processing, protection and support of environmental balance, cultural development and preservation of cultural heritage, art, science, innovative development and respect for consumer rights [6].

One should say that there is indispensable correlation between social entrepreneurship and inclusive development, because this innovative form of management involves pervasiveness of all groups of residents: on the one hand - employment opportunities for young people, on the other - quality and affordable services to vulnerable groups of people due to the income gap reduction between the poor and the rich [7].

The following models of social business are considered to be the most effective in Ukraine [1]: the model of effective employment; service commercialization model; market intermediation model; model of supporting the initiative of youth entrepreneurs; model of investing in social programmes through equitable redistribution and others. The above models typically combine several types, which determines their effectiveness.

The global trend is to form and support of an inclusive team functioning by involving people who may differ in experience, gender, age, nationality, lifestyle, cultural characteristics, temperament, attitude to work, results and more. This is like inclusive employment, which, according to the Western experts, contributes to additional tangible and intangible benefits, rises positive socio-economic impact on social environment through public recognition and respect [8].

Social entrepreneurship is an effective tool for solving social and individual problems: for entrepreneurs it is the possibility of personal development and self-employment, for an individual it is the way of solving social problems, and for society it ensures socio-economic development, improves living standards and forms state's positive image at the international level. The main objective of social entrepreneurship is to identify and practically 
solve a social problem by using innovative methods or creative ways to adapt traditional business practices to the characteristics of market environment. That is, any social problem determines the need for the development of social entrepreneurship in a particular area.

We agree that social entrepreneurship development and effective functioning needs certain environment in a country, which depends on sustainable factors. The economies are significantly affected by current global challenges, which have both negative and positive consequences for socio-economic development, regardless of the country's international ranking. The higher the level of development a country has, the greater the opportunities to choose the development trend and move along a certain trajectory with few social losses. The resource potential and potential of developing countries are insufficient to overcome threats' negative consequences facing humanity.

\section{Conclusions}

The study reveals that traditional managerial methods have proved ineffective in meeting people needs and implementation of personal and public interests. Social entrepreneurship becomes one of the sources of social stability and employment for young people, as well as an opportunity for maximum self-realization. Of course, the social entrepreneurship business model does not solve all the existing problems, but creates opportunities to reduce their negative impact by successful combination of an innovative business model with market managerial methods. The duality of social enterprises is not only a combination of profit and non-profit goals, but also a balance between social (solving socio-economic problems) and personal development of an entrepreneur (enrichment, energy, selfrealization, self-improvement and social consciousness).

\section{References}

1. Bank problem ta modelej sotsialnykh pidpryemstv dlia yikh virishennia [Bank of problems and models of social enterprises for their solution]. 13.09.2018. 58 c. URL: https://d.facebook.com/civichuborg/? tn__ $=\% 2 \mathrm{Cg}$. [in Ukrainian].

2. Makeychek, Yu. N. Prakticheskie aspekty soczialnogo predprinimatelstva v Belarusi [Practical aspects of social entrepreneurship in Belarus]. Minsk : Kapital Print, 2018. 226 s. [in Russian].

3. Pryshchak, M. D., Lesko, O. Y. (2016) Psykholohiia upravlinnia v orhanizatsii [Management Psychology in Organization]. Vinnytsia: VNTU, 2016. 150 s. [in English].

4. Horishna, N.M. (2016) Fenomen sotsialnoho pidpryiemnytstva: sutnist i kryterii [The phenomenon of social entrepreneurship: essence and criteria]. Naukovyi Visnyk Uzhhorodskoho universytetu. Seriia: «Pedahohika. Sotsialna robota». Vypusk 2 (39). S. 58-61. [in Ukrainian].

5. The social enterprise sector : a conceptual framework / Organisation for Economic Co-operation and Development (OECD), Local Economic and Employment Development Programme (LEED Programme). URL: http://www.oecd.org/regional/leed/37753595. [in English].

6. European Commission.Growth. Sectors of the Social economy in the EU: Social enterprises. URL: https://ec.europa.eu/growth/sectors/social-economy/enterprises_en [in English].

7. Uchastie biznesa $v$ reshenii problemy bednosti. Kak inklyuzivnye modeli vedeniya biznesa sozdayut vozmozhnosti dlya vsekh zhitelej razvivayushhikhsya stran Evropy i Czentralnoj Azii [Business participation in solving the problem of poverty. How inclusive business models create opportunities for all people in developing countries in Europe and Central Asia]. 2010. 16 c. URL: www.growinginclusivemarkets.org. [in Russian].

8. Scaling up Inclusive Business: Advancing the Key Knowledge and Action Agenda, IFC, 2010. URL: https://www.ifc.org/wps/wcm/connect/topics_ext_content/ifc_external_corporate_site[in English]. 